\title{
PENGARUH INSENTIF, PELATIHAN DAN DISIPLIN KERJA TERHADAP KINERJA PEGAWAI PADA KANTOR SAR SEMARANG
}

\author{
Endah Muktiani \\ SAR Semarang, email endahmuktiani1908@gmail.com
}

\begin{abstract}
ABSTRAK
Penelitian ini bertujuan untuk mengetahui seberapa besar pengaruh parsial dan simultan antara insentif, pelatihan dan disiplin kerja terhadap kinerja pegawai pada kantor SAR Semarang. Populasi dalam penelitian ini adalah seluruh pegawai kantor SAR Semarang sebanyak 60 orang. Pengambilan sampel dilakukan dengan metode sensus, sehingga seluruh pegawai kantor SAR Semarang sebanyak 60 pegawai dijadikan sampel. Data yang digunakan dalam penelitian ini yaitu data primer dan data sekunder, kemudian dilanjutkan dengan analisis regresi linier berganda dengan bantuan program IBM SPSS Statistics 19. Hasil analisis menunjukkan bahwa insentif, pelatihan dan disiplin kerja berpengaruh positif signifikan terhadap kinerja pegawai baik secara parsial maupun secara simultan. Sehingga untuk meningkatkan kinerja pegawai pada kantor SAR Semarang dibutuhkan peningkatan insentif, pelatihan dan disiplin kerja yang baik.
\end{abstract}

Kata Kunci: Insentif, Pelatihan, Disiplin Kerja dan Kinerja Pegawai

\section{PENDAHULUAN}

\section{Latar Belakang Masalah}

Wilayah Negara kesatuan Republik Indonesia yang terdiri dari pulau-pulau besar dan kecil dari Sumatera sampai dengan Merauke (kota Merauke) di Pulau Irian (Papua) yang berbatasan dengan Negara Papua Nugini. Karena wilayahnya terdiri dari pulau-pulau dan lautan/perairan maka Negara Indonesia juga disebut nusantara yang artinya nusa dan antara berarti pulau. Jadi bila disimpulkan wilayah Indonesia terdiri antara pulau dengan yang dipisahkan dengan perairan. Indonesia disebut negara maritim karena $2 / 3$ wilayah Indonesia adalah perairan sedangkan 1/3-nya wilayah Indonesia adalah perairan (maritim).

Wilayah Indonesia berada di garis khatulistiwa yang dilintasi matahari dari Timur ke Barat yang merupakan daerah tropis, tanah yang subur dengan sumber hayati seperti pertanian, hutan, hasil laut (perikanan) yang melimpah ruah yang perlu dikelola dengan sebaik-baiknya dengan memperhatikan lingkungan hidup dan ekosistem dengan tidak menimbulkan kerusakan alam dan kehidupan hayati di seluruh wilayah Indonesia. Disamping itu, sumber daya mineral juga perlu dikelola dengan sebaik-baiknya, maka kehidupan binatang (hewani) dan tumbuh-tumbuhan akan terjaga dan terlindungi sehingga tidak terjadi kepunahan yang pada akhirnya kehidupan manusia dengan alam di sekitarnya akan terjadi keseimbangan dan saling membutuhkan. Apabila hal tersebut tidak dikelola dengan baik akan menimbulkan bencana yang berdampak pada terancamnya jiwa manusia dan harta benda. Karena Indonesia disebut negara kepulauan atau negara maritim tentu saja terjadi penyebaran penduduk dari pulau satu ke pulau lainnya. Begitu pula hasil pertanian, kehutanan, perikanan, tambang (mineral), pariwisata serta perdagangan yang semua itu perlu pendistribusian hasil-hasil dimaksud yang sudah barang tentu memerlukan kesiapan sarana transportasi darat, laut dan udara yang memadai sesuai dengan kebutuhan penduduk. Hal ini akan menimbulkan kepadatan arus 
transportasi yang meliputi 3 (tiga) moda tersebut. Dengan meningkatnya pengguna jasa transportasi akan menimbulkan kerawanan kecelakaan lalu lintas seperti:

a. Kecelakaan transportasi darat misalnya tabrakan kereta api, kecelakaan mobil/sepeda motor.

b. Kecelakaan transportasi laut misalnya: kapal tabrakan, terbakar dihantam ombak dan akhirnya tenggelam.

c. Kecelakaan transportasi udara misalnya: pesawat jatuh dan terbakar, menabrak, gagal tinggal landas dan lain-lain.

Pemerintah Indonesia telah menerbitkan Peraturan Pemerintah Nomor 36 Tahun 2006 tentang Pencarian dan Pertolongan dengan kelembagaannya disebut Badan SAR Nasional dimana keorganisasiannya diatur melalui Peraturan Presiden No. 99 Tahun 2007 tentang Organisasi Badan SAR Nasional yang merupakan Lembaga Pemerintah Non Kementerian (LPNK) yang bertanggung jawab langsung kepada Presiden. Dengan keberadaan lembaga yang dibentuk pemerintah diharapkan lembaga tersebut mampu menangani musibah dan bencana pada tingkat tanggap darurat apabila terjadi musibah dan bencana sewaktu-waktu dengan cepat, tepat, aman dan handal.

Pencarian dan pertolongan (Search And Rescue) atau disingkat SAR berdasarkan PP No. 36 Tahun 2006 adalah meliputi usaha dan kegiatan mencari, menolong dan menyelamatkan jiwa manusia yang hilang atau dikhawatirkan hilang atau menghadapi bahaya dalam musibah pelayaran dan/ atau penerbangan, atau bencana/musibah lainnya. Pelaksanaan pencarian dan pertolongan (Search and Rescue) dikoordinasikan oleh Badan Search and Rescue Nasional disingkat Badan SAR Nasional yang berada di bawah dan bertanggung jawab langsung kepada Presiden. Organisasi Badan SAR Nasional terdiri dari Organisasi Tingkat Pusat yaitu disebut Badan SAR Nasional, sedangkan Organisasi Tingkat Daerah yang berada di tingkat Propinsi Kabupaten/Kota disebut Kantor Search and Rescue (SAR). Namun demikian, belum semua propinsi dan Kabupaten/Kota terdapat Kantor Search and Rescue (SAR).
Kedudukan, tugas dan fungsi Badan SAR Nasional berdasarkan Peraturan Presiden Nomor 99 Tahun 2007 adalah Lembaga Pemerintah Non Departemen yang berada di bawah dan bertanggung jawab kepada Presiden dalam melaksanakan tugas pemerintah dibidang pencarian dan pertolongan (Search and Rescue) yang selanjutnya disebut SAR sesuai dengan ketentuan peraturan perundang-undangan. Di samping itu, Badan SAR Nasional mempunyai fungsi: perumusan kebijakan, koordinasi, perencanaan, pembinaan, pengerahan dan pengendalian potensi SAR, siaga, tindak awal dan operasi SAR, penyelenggaraan diklat dan pemasyarakatan SAR, hubungan kerja sama, pengelolaan Barang Milik Negara, pelayanan administrasi, pengawasan dan pelaporan.

Kantor Search and Rescue yang selanjutnya disebut Kantor SAR yang berada di seluruh wilayah Indonesia yang dibentuk berdasarkan Peraturan Kepala Badan SAR Nasional No. PK.08 Tahun 2010, Kantor SAR adalah Unit Pelaksana Teknis (UPT) Badan SAR Nasional dalam bidang pencarian dan pertolongan (Search And Rescue) yang wilayah tanggung jawabnya dan bertanggung jawab kepada Kepala Badan SAR Nasional.

Kantor SAR Semarang adalah satu dari 38 kantor SAR yang ada di seluruh Indonesia berada di propinsi Jawa Tengah yang menangani musibah/bencana sesuai PP No. 36 tahun 2006. Namun demikian, apabila diperlukan dimungkinkan dapat melaksanakan tugas di luar propinsi Jawa Tengah atau bahkan ke seluruh wilayah Indonesia tentunya didasarkan azas efektif dan efisien. Kantor SAR Semarang mempunyai perwakilan di 3 (tiga) Pos SAR dan Unit Siaga SAR yaitu : Pos SAR Cilacap, Pos SAR Jepara, Pos SAR Surakarta dan Unit Siaga SAR Wonosobo.

Adapun jumlah personil kantor SAR Semarang sebagai berikut :
a. Tenaga Rescuer
: 90 orang
b. Tenaga Pendukung : 16 orang
c. Tenaga Administrasi : 19 orang

Dengan tingkat pendidikan SMA atau sederajat : 98 orang; D3 : 7 orang dan S1 : 20 orang yang ditempatkan di 3 (tiga) Pos SAR dan 1 (satu) Unit Siaga SAR dengan personil sebagai berikut: 
Tabel 1.1

Data personil pegawai pada Kantor SAR Semarang

\begin{tabular}{|l|l|l|l|}
\hline No & Keterangan & Rescuer & Adminstrasi \\
\hline 1 & Kantor SAR Semarang & 60 orang & 22 orang \\
\hline 2 & Pos SAR Cilacap & 10 orang & 3 orang \\
\hline 3 & Pos SAR Jepara & 10 orang & 2 orang \\
\hline 4 & Pos SAR Surakarta & 10 orang & 2 orang \\
\hline 5 & Unit Siaga SAR Wonosobo & 5 orang & \\
\hline \multicolumn{2}{|l|}{ Total } & orang & orang \\
\hline
\end{tabular}

Sumber : Daftar Nominatif Kantor SAR Semarang

Setelah diuraikan permasalahan musibah/bencana yang silih berganti dari satu tempat ke tempat lain di wilayah Indonesia, keberadaan organisasi/lembaga Badan SAR Nasional sangat diharapkan masyarakat dan untuk dapat dimanfaatkan secara optimal dalam mengantisipasi dan penanganan terjadi musibah/bencana pada setiap waktu, tempat untuk mengurangi risiko/korban jiwa yang timbul akibat musibah/bencana. Perlu kita ketahui bahwa setiap terjadi musibah/bencana tidak hanya Badan SAR Nasional saja yang mengambil peran namun diperlukan peran BNPB, TNI/POLRI, instansi pemerintah/swasta, organisasi sosial kemanusiaan, organisasi kepemudaan dan organisasi kemasyarakatan juga ikut ambil bagian dalam setiap operasi SAR. Oleh sebab itu, disini diperlukan peran komunikasi dan koordinasi.

Menyadari betul bahwa tidak ada satu instansi yang dapat menangani musibah/bencana tanpa peran organisasi lainnya. Keragaman unit SAR yang ada di lapangan pada saat operasi penyelematan perlu diatur dalam satu komando oleh Badan SAR Nasional. Perlu ditegaskan di sini bahwa keterlibatan Badan SAR Nasional dalam operasi pencarian dan penyelamatan terhadap musibah/bencana, pada tahapan tingkat tanggap darurat dimana pada tingkatan ini terjadi korban dan diperlukan kecepatan tindakan untuk menyelamatkan jiwa manusia dari ancaman kematian akibat dari musibah/bencana.

Dalam perjalanannya Badan SAR Nasional dalam melaksanakan tugas evaluasi pencarian, pertolongan, penyelamatan dan evakuasi terhadap korban jiwa manusia yang disebabkan oleh musibah/bencana di berbagai wilayah Indonesia tentu saja banyak mengalami kendala yang dihadapi tim SAR di lapangan. Hal ini disebabkan beberapa faktor yang mempengaruhi antara lain: faktor alam (lokasi/medan dan cuaca), faktor peralatan, faktor kebijakan pemerintah dan sumber daya manusia dan masih banyak faktor lainnya. Dengan adanya faktor yang mempengaruhi menyebabkan hal-hal sebagai berikut:

1. Keterlambatan respon time tim SAR tiba di tempat musibah. Hal ini disebabkan lokasi/tempat musibah berjauhan dengan kantor SAR dan Pos SAR. Di samping itu, belum semua kota/kabupaten di wilayah Jawa Tengah terdapat pos SAR.

2. Faktor alam, yang meliputi cuaca dan medan yang sulit (misalnya: cuaca buruk, lokasi musibah di gunung/tebing/lautan luas dan gelombang tinggi). Hal ini menyulitkan pencarian dan pertolongan.

3. Faktor terbatasnya peralatan meliputi peralatan utama dan pendukung (misalnya: perahu karet, alat-alat selam, alat mountaineering dan kendaraan operasional yang merupakan menjadi salah satu hambatan.

4. Faktor kebijakan pemerintah dalam hal perhatian terhadap pengembangan organisasi Badan SAR Nasional masih rendah. Hal ini terbukti dengan minimnya anggaran yang disediakan untuk pembelian/pengadaan alat utama dan biaya operasional. 
5. Faktor sumber daya manusia. Keberhasilan dalam setiap operasi SAR tidak hanya ditentukan oleh faktor tersebut di atas seperti faktorfaktor respon time, alam, peralatan, kebijakan dan pemerintah melainkan faktor sumber daya manusia juga turut menentukan keberhasilan dalam setiap usaha/kegiatan pencarian dan pertolongan.

Sumber Daya Manusia yang ada dari segi jumlah dan kualitas masih kurang memadai. Guna meningkatkan kinerja sumber daya manusia yang ada, perlu meningkatkan pendidikan dan pelatihan secara berjenjang dan berkelanjutan serta pendidikan spesial guna membekali diri setiap insan rescuer secara perorangan/kelompok petugas SAR dituntut bekerja secara cepat dan professional, guna memperkecil resiko korban akibat musibah/bencana kekurangan jumlah personil perlu ditambah.

Selain tugas-tugas operasi SAR, tim SAR melakukan pembinaan dan pelatihan terhadap kelompok/organisasi sosial kemanusiaan dan instansi pemerintah yang terkait dengan kegiatan Search And Rescue (SAR). Disamping tugas-tugas tersebut di atas Kantor SAR Semarang juga melaksanakan tugas/kegiatan koordinasi dengan instansi yang berpotensi SAR guna menyatukan persepsi, sehingga apabila terjadi musibah/bencana pelaksanaan operasi dapat berjalan secara terpadu dan terkoordinasi dengan satu komando dan diharapkan berjalan dengan lancar, aman dan terkendali.

Pembinaan sumber daya manusia dimaksudkan untuk meningkatkan kualitas dan profesionalisme kinerja pegawai sehingga dapat mendukung tercapainya sasaran pembinaan yang diharapkan sesuai dengan tugas pokok dan fungsi Kantor SAR Semarang. Pembinaan SDM dilaksanakan melalui program pendidikan/pelatihan dan latihan di bidang Search And Rescue (SAR) yang merata dan bermutu disertai peningkatan dan perluasan pendidikan/pelatihan dan latihan serta keahlian yang dibutuhkan. Disamping adanya program pendidikan/pelatihan sesuai keahlian dalam bidang tugas perlu juga diselenggarakan diklat penjenjangan. Pendidikan dalam konteksnya spesial/khusus yang diperuntukkan untuk petugas khusus yang terkait tugas kemanusiaan. Ada beberapa jenis pendidikan dan pelatihan sebagai berikut :

a) Pendidikan dan Pelatihan

1) Diklat internal Basarnas;

2) Diklat eksternal untuk potensi SAR;

3) Latihan/ pembinaan potensi SAR;

4) Penyuluhan dan pemasyarakatan SAR.

b) Jenis Diklat Teknik SAR

1) Diklat SAR tingkat dasar;

2) Diklat SAR tingkat lanjutan;

3) Diklat SAR tingkat spesialis;

4) Diklat SAR tingkat manajerial;

5) Diklat SAR pendukung;

6) Diklat SAR potensi.

c) Diklat SAR tingkat dasar

Diperuntukkan untuk seluruh PNS / CPNS Basarnas.Diklat lanjutan adalah diklat setelah mengikuti Diklat SAR tingkat Dasar. Diklat ini meliputi :

1) Medical First Responder (MFR)

2) High Angle Rescue Technique (HART)

3) Jungle Rescue

4) Water Rescue

5) Road Accident Rescue (RAR)

6) Hely Rescue

7) Confined Space Rescue

8) Collapsed Structure Search And Rescue (CSSR)

9) Fire Rescue

10) Pelatihan ABK (Anak Buah Kapal).

d) Diklat SAR tingkat spesialis.

1) SAR Planning;

2) Diving Rescue (Penyelam Penolong).

e) Diklat Pendukung

1) Operator radio

2) Teknisi radio

3) Operator Mission Coordinator Center / Local User Terminal

4) Diklat SAR Penanggulangan Bencana

5) Basic Safety Training (BST), dll.

f) Pelatihan

1) Gladi Posko (CPX);

2) Gladi Lapangan (Manuver)

g) Sarana Utama SAR

1) Helicopter Dauphin AW139, Helicopter Bolco BO105

2) Rigid Inflatable Boat

3) Hovercraft 
4) GPS (Global Positioning System)

5) Rescue Boat, kapal layar motor, rubber boat

6) Sarana angkutan darat / ambulans

7) Equipment mountaineering

8) Tim Rescue

9) PPGD

10) Sarana komunikasi dan elektronik.

Selain tugas-tugas operasi SAR, tim SAR melakukan pembinaan dan pelatihan terhadap kelompok/organisasi sosial kemanusiaan dan instansi pemerintah yang terkait dengan kegiatan Search And Rescue (SAR). Di samping tugas-tugas tersebut di atas Kantor SAR Semarang juga melaksanakan tugas/kegiatan koordinasi dengan instansi yang berpotensi SAR guna menyatukan persepsi, sehingga apabila terjadi musibah/bencana pelaksanaan operasi dapat berjalan secara terpadu dan terkoordinasi dengan satu komando dan diharapkan berjalan dengan lancar, aman dan terkendali.

\section{Perumusan Masalah}

1. Apakah ada pengaruh insentif terhadap terhadap kinerja pegawai pada Kantor SAR Semarang?

2. Apakah ada pengaruh pelatihan terhadap terhadap kinerja pegawai pada Kantor SAR Semarang?

3. Apakah ada pengaruh disiplin kerja terhadap terhadap kinerja pegawai pada Kantor SAR Semarang?

4. Apakah insentif, pelatiahan, dan disiplin kerja berpengaruh secara bersama-sama terhadap kinerja pegawai pada Kantor SAR Semarang?

5. Variabel manakah yang paling berpengaruh terhadapa kinerja pegawai pada Kantor SAR Semarang?

\section{Tujuan Penelitian}

1. Untuk menguji dan menganalisis pengaruh insentif terhadap kinerja pegawai pada Kantor SAR Semarang.

2. Untuk menguji dan menganalisis pengaruh pelatihan terhadap kinerja pegawai pada Kantor SAR Semarang.

3. Untuk menguji dan menganalisis pengaruh disiplin kerja terhadap kinerja pegawai pada Kantor SAR Semarang.

4. Untuk menguji dan menganalisis apakah insentif, pelatihan, dan disiplin kerja berpengaruh secara bersama-sama terhadap kinerja pegawai pada Kantor SAR Semarang.

5. Untuk menguji dan menganalisis variabel manakah yang paling berpengaruh terhadap kinerja pegawai pada Kantor SAR Semarang.

\section{Landasan Teori \\ Kinerja Pegawai}

Menurut Robbins (2003) bahwa kinerja adalah sebagai fungsi dari interaksi antara kemampuan dan motivasi. Dalam studi manajemen kinerja pekerja atau ada hal yang memerlukan pertimbangan yang penting, sebab kinerja individual seorang dalam organisasi merupakan bagian dari kinerja organisasi, dan dapat menentukan kinerja dari organisasi tersebut. Berhasil tidaknya kinerja yang telah dicapai organisasi tersebut, akan dipengaruhi oleh tingkat kinerja dari secara individu maupun kelompok. Russel (2003) mengemukakan bahwa kinerja sebagai catatan keberhasilan yang dihasilkan dari fungsi suatu pekerjaan tertentu/kegiatan selama periode tertentu. Menurutnya ada enam kategori untuk mengukur kinerja pegawai, yaitu: kualitas, kuantitas, ketepatan waktu, efektifitas, kemandirian dan komitmen. sedangkan Byors dan Rue (2006) kinerja merupakan derajat penyelesaian tugas yang menyertai pekerjaan seseorang yang seberapa baik individu memenuhi permintaan pekerjaan.

Dari pengertian-pengertian kinerja di atas, maka kinerja dapat diartikan sebagai catatan keberhasilan dari suatu pekerjaan/tugas yang telah dicapai seseorang, melalui pengevaluasian/penilaian kinerja pegawai, merupakan hasil yang bersifat kualitatif dan kuantitatif. Seperti dikatakan bahwa kinerja telah menjadi kerangka pikir sentral untuk dijadikan pemicu pencapaian tujuan organisasi bisnis. Namun hingga saat ini belum ada satupun yang dapat dianggap sebagai teori umum tentang kinerja tersebut (Guest 2007). Teori tentang kinerja tersebut dimaksudkan untuk dapat menjelaskan memberikan suatu peramalan dan mengendalikan kinerja di masa yang akan datang. Penjelasan tentang kinerja yang ada saat ini, kerap kali dikaitkan dengan masalah kriteria. Dengan kata lain, kinerja menjadi tolok ukur untuk dikatakan suatu aktivitas berjalan sesuai rencana atau tidak. 
Nawawi (2005) menyatakan bahwa, "Kinerja adalah hasil pelaksanaan suatu pekerjaan, baik bersifat fisik/material maupun non fisik/non material". Mathis dan Jackson (2006) menyatakan bahwa, "Kinerja (performance) pada dasarnya adalah apa yang dilakukan atau tidak dilakukan oleh karyawan. Kinerja karyawan yang umum untuk kebanyakan pekerjaan meliputi elemen sebagai berikut: (1) kuantitas dari hasil, (2) kualitas dari hasil, (3) ketepatan waktu dari hasil, (4) kehadiran, dan (5) kemampuan bekerja sama.". Menurut Simanjuntak (2005), "Kinerja adalah tingkat pencapaian hasil atas pelaksanaan tugas tertentu. Simanjuntak juga mengartikan kinerja individu sebagai tingkat pencapaian atau hasil kerja seseorang dari sasaran yang harus dicapai atau tugas yang harus dilaksanakan dalam kurun waktu tertentu". Foster dan Seeker (2001) menyatakan bahwa, "Kinerja adalah hasil yang dicapai seseorang menurut ukuran yang berlaku untuk pekerjaan yang bersangkutan”.

\section{Insentif}

Menurut Lawler (2001), sistem penghargaan (reward system) dalam suatu organisasi atau perusahaan akan berdampak pada keefektifan dan juga kinerja dalam organisasi tersebut. Karyawan dapat mencapai tujuan tertentu dan perilaku individu dengan mendesain suatu sistem penghargaan yang tepat.

Suatu sistem penghargaan atau sistem kompensasi merupakan mekanisme yang penting dalam mengintegrasikan usaha individu yang diarahkan pada tujuan strategi perusahaan dan jika desainnya tepat dapat dijadikan kunci bagi keefektifan perusahaan (Gomez dkk. 1988 dikutip oleh Hartono 2008). Dengan melihat pentingnya desain sistem penghargaan, maka desain tersebut harus dapat menarik dan memotivasi kinerja. Hal ini terkait dengan kepentingan perusahaan yang juga mengharapkan desain sistem kinerja dapat menunjang keberhasilan perusahaan pada masa mendatang.

Jenis penghargaan dapat berasal dari dalam individu (intrinsic reward) maupun luar individu (extrinsic reward). Intrinsic reward merupakan penghargaan yang berasal dari dalam diri seseorang dan diwujudkan dalam bentuk peningkatan perasaan untuk berprestasi, bertanggung jawab, dan memiliki otonomi dalam membuat keputusan. Sedangkan extrinsic reward merupakan penghargaan yang berasal dari luar yang diwujudkan dalam bentuk gaji, promosi, pujian dari atasan dan fasilitas dari kantor.

\section{Pelatihan}

Menurut Notoatmodjo (2009), pendidikan dan pelatihan adalah upaya untuk pengembangan sumber daya manusia, terutama untuk pengembangan aspek kemampuan intelektual dan kepribadian manusia. Perbedaan istilah pendidikan dan pelatihan dalam suatu organisasi, secara teori dijelaskan bahwa pendidikan adalah suatu proses pengembangan kemampuan ke arah yang diinginkan oleh organisasi yang bersangkutan, sedangkan pelatihan merupakan bagian dari proses pendidikan yang bertujuan meningkatkan kemampuan atau keterampilan khusus seseorang atau kelompok orang. Menurut Arep (2003), pelatihan merupakan salah satu usaha untuk mengembangkan sumber daya manusia, terutama dalam hal pengetahuan, kemampuan, keahlian, dan sikap.

Menurut Sunarto dan Sahedhy (2001) menyatakan, pelatihan kerap dibedakan dari pendidikan. Pendidikan dianggap lebih luas lingkupnya dengan tujuan mengembangkan individu, sedangkan pelatihan merupakan upaya meningkatkan kinerja pegawai pada pekerjaan yang didudukinya sekarang untuk membantu menunaikan pekerjaan mereka saat ini secara lebih baik. Manfaat finansial pelatihan bagi organisasi biasanya terjadi dengan segera. Pengembangan didasarkan pada fakta bahwa seorang pegawai akan membutuhkan serangkaian pengetahuan, keahlian dan kemampuan yang berkembang supaya bekerja dengan baik dalam suksesi posisi yang ditemui selama kariernya. Pengembangan lebih terfokus pada kebutuhan jangka panjang umum organisasi, hasilnya bersifat tidak langsung dan hanya dapat diukur dalam jangka panjang.

\section{Disiplin Kerja}

Disiplin merupakan sikap, tingkah laku dan perbuatan yang sesuai dengan peraturan perusahaan baik yang tertulis maupun yang tidak tertulis. Peraturan yang dimaksud termasuk absensi, lambat masuk, serta cepat pulang karyawan. Jadi hal ini merupakan 
suatu sikap indisipliner karyawan yang perlu disikapi dengan baik oleh pihak manajemen. Banyak yang mengartikan disiplin itu bilamana karyawan selalu datang serta pulang tepat pada waktunya. Pendapat itu hanya salah satu yang dituntut oleh organisasi. Oleh karena itu, kedisiplinan dapat diartikan sebagai tingkah laku yang tertulis maupun yang tidak tertulis. (Hasibuan, 2009).

Menurut Rivai (2009) Disiplin kerja dapat mendefenisikan sebagai suatu sikap menghormati, menghargai, patuh dan taat terhadap peraturan-peraturan yang berlaku, baik yang tertulis maupun tidak tertulis serta sanggup menjalankannya dan tidak mengelak untuk menerima sanksi-sanksinya apabila ia melanggar tugas dan wewenang yang diberikan kepadanya. Kedisiplinan merupakan fungsi operatif MSDM yang terpenting, karena semakin baik disiplin karyawan pada perusahaan, maka semakin tinggi prestasi kerja yang dapat dicapai.

Disiplin kerja adalah perilaku seseorang yang sesuai dengan peraturan, prosedur kerja yang ada atau disiplin adalah sikap, tingkah laku dan perbuatan yang sesuai dengan peraturan dari organisasi baik tertulis maupun yang tidak tertulis. (Sutrisno, 2009). Disiplin kerja adalah suatu alat yang digunakan para manajer untuk berkomunikasi dengan karyawan agar mereka bersedia untuk mengubah suatu perilaku serta sebagai suatu upaya untuk meningkatkan kesadaran dan kesediaan seseorang untuk mentaati semua peraturan perusahaan dan norma-norma sosial yang berlaku. (Rivai, 2009).

\section{Hipotesis}

H1: Insentif berpengaruh positif terhadap kinerja pegawai

$\mathrm{H} 2$ : Pelatihan berpengaruh positif terhadap kinerja pegawai.

H3: Disiplin kerja berpengaruh positif terhadap kinerja pegawai.

\section{METODE PENELITIAN \\ Populasi dan Sampel}

Menurut Arikunto (2006) populasi adalah keseluruhan subyek penelitian. Dengan demikian populasi adalah keseluruhan subyek penelitian yang akan dikenai generalisasi berdasarkan pada sampel dari suatu penelitian. Sedangkan Populasi dalam penelitian ini meliputi semua pegawai yang bekerja pada Kantor SAR Semarang. Jadi untuk jumlah keseluruhan populasi dalam penelitian ini adalah sejumlah 60 pegawai.

Metode penentuan sampel dalam penelitian ini metode populasi Sampling atau Sensus. Menurut Arikunto (2006) dikemukakan bahwa untuk mengambil sampel dengan populasi kurang dari 100, maka diambil semua, sehingga penelitiannya merupakan penelitian populasi. Jumlah sampel penelitian sebanyak 60 Pegawai.

\section{Metode Pengumpulan Data}

Teknik pengumpulan data yang digunakan dalam penelitian adalah:

a. Kuesioner

Kuesioner adalah metode pengumpulan data yang dilakukan dengan cara memberikan pernyataan-pernyataan kepada responden dengan panduan kuesioner. Kuesioner merupakan metode untuk mendapatkan data dengan cara menyajikan daftar pernyataan yang telah dibuat terlebih dahulu, yang diajukan kepada responden sebagai objek penelitian. Kuesioner yang diberikan kepada responden berupa pernyataan disertai dengan penilaian terhadap pernyataan tersebut dengan menggunakan skala likert 1 sampai 5 (Sunyoto 2013). Jawaban responden yang bersifat bebas/terbuka sesuai dengan yang dilakukan, dialami dan dirasakan tanpa adanya pengaruh dari siapapun. Pemberian skor pernyataan pada skala likert dengan ketentuan sebagai berikut:

Tabel 3.1

Bobot Penilaian Kuesioner

\begin{tabular}{|c|c|c|c|}
\hline No & Jawaban & & $\begin{array}{c}\text { Bobot } \\
\text { Penilaian }\end{array}$ \\
\hline 1 & Sangat Setuju & SS & 5 \\
\hline 2 & Setuju & S & 4 \\
\hline 3 & Kurang Setuju & KS & 3 \\
\hline 4 & Tidak Setuju & TS & 2 \\
\hline 5 & $\begin{array}{c}\text { Sangat Tidak } \\
\text { Setuju }\end{array}$ & STS & 1 \\
\hline
\end{tabular}

Selanjutnya data yang diperoleh dari jawaban responden dikumpulkan dan dimasukan ke dalam tabel sebagai data primer (tabulating). Data primer yang terkumpul diolah dengan menggunakan program statistic SPSS for windows ver.16.0.

b. Dokumenter 
Dokumenter yaitu metode pengumpulan data dengan pencatatan dari dokumen pada objek penelitian yang berhubungan dengan data jumlah pegawai pada Kantor SAR Semarang.

c. Observasi

Observasi merupakan metode penelitian dimana peneliti melakukan pengamatan secara langsung pada objek penelitian.

\section{d. Studi Pustaka}

Studi pustaka merupakan cara pengambilan data dengan menggunakan barang-barang tertulis, buku-buku, majalah, jurnal dokumen peraturan, notulen rapat, catatan harian yang berhubungan dengan penelitian (Arikunto 2006). Dalam hal ini data yang terkait dengan variabel-variabel dalam penelitian.

\section{Teknik Analisis Data}

Data yang digunakan dalam penelitian ini adalah jawaban dari kuesioner yang telah disebarkan kepada responden. Data tersebut dianalisis dengan metode analisis jalur dengan bantuan program SPSS for windows ver.16.0.

\section{HASIL DAN PEMBAHASAN}

Hipotesis pertama (H1) dalam penelitian ini Ada pengaruh positif disiplin kerja terhadap produktivitas kerja karyawan Area Layanan Mikro Bank Jateng Cabang Pemalang. Berdasarkan hasil pengujian hipotesis yang dapat dilihat melalui tabel 4.16 uji statistik t, untuk variabel disiplin diperoleh hasil tingkat signifikansi sebesar 0,904 yang menunjukkan lebih besar dari 0,05 $(\alpha=5 \%)$. Dengan demikian $\mathrm{H}_{0}$ diterima dan $\mathrm{H}_{\mathrm{a}}$ ditolak. Maka dapat di simpulkan bahwa tidak ada pengaruh positif disiplin kerja terhadap produktivitas kerja karyawan Area Layanan Mikro Bank Jateng Cabang Pemalang.

Hipotesis kedua (H2) dalam penelitian ini Ada pengaruh positif motivasi kerja terhadap produktivitas kerja karyawan Area Layanan Mikro Bank Jateng Cabang Pemalang. Untuk variabel motivasi diperoleh hasil tingkat signifikansi sebesar 0,021 yang menunjukkan lebih kecil dari $0,05(\alpha=5 \%)$. Dengan demikian $\mathrm{H}_{0}$ ditolak dan $\mathrm{H}_{\mathrm{a}}$ diterima. Maka dapat di simpulkan bahwa ada pengaruh positif motivasi kerja terhadap produktivitas kerja karyawan Area Layanan Mikro Bank Jateng Cabang Pemalang.

Hipotesis ketiga (H3) dalam penelitian ini Ada pengaruh positif pengalaman kerja terhadap produktivitas kerja karyawan Area Layanan Mikro Bank Jateng Cabang Pemalang. Untuk variabel pengalaman diperoleh hasil tingkat signifikansi sebesar 0,026 yang menunjukkan lebih kecil dari 0,05 $(\alpha=5 \%)$. Dengan demikian $\mathrm{H}_{0}$ ditolak dan $\mathrm{H}_{\mathrm{a}}$ diterima. Maka dapat di simpulkan bahwa ada pengaruh positif pengalaman kerja terhadap produktivitas kerja karyawan Area Layanan Mikro Bank Jateng Cabang Pemalang.

\section{Pengaruh Disiplin terhadap Produktivitas}

Hasil analisis menunjukan bahwa Disiplin Kerja tidak ada berpengaruh positif terhadap produktivitas karyawan. Ini artinya bahwa dengan teori Disiplin Kerja yang di ukur melalui 3 indikator yaitu Disiplin Waktu, Disiplin Peraturan dan Disiplin Tanggung Jawab. Dengan regresi berganda menunjukan arti bahwa Disiplin Kerja tidak ada pengaruh positip terhadap produktivitas Karyawan area layanan mikro cabang Pemalang.

Disiplin kerja karyawan area layanan mikro cabang Pemalang masih rendah, hal ini dapat dilihat dari kurangnya kesadaran dan kesediaan para karyawan untuk menaati semua peraturan yang dibuat oleh perusahaan. Pandangan ini menjelaskan bahwa suatu kerelaan dan kesediaan seseorang dalam mentaati peraturan peraturan yang berlaku tanpa paksaan. Sehingga dapat disimpulkan bahwa kedisiplinan kerja tidak dapat mendorong para karyawan area layanan mikro cabang pemalang untuk bekerja lebih keras dan lebih baik dalam menyelesaikan setiap pekerjaan yang diberikan oleh pimpinan. Jadi dapat dikatakan bahwa kedisiplinan kerja tidak ada berpengaruh terhadap produktivitas kerja area layanan mikro cabang Pemalang.

Dengan demikian penelitian ini sejalan dan mendukung hasil penelitian sebelumnya yang dilakukan oleh Dwi Agung N, A,. (2013) yang menunjukan bahwa Disiplin Kerja tidak ada pengaruh positif terhadap Produktivitas Karyawan.

\section{Pengaruh Motivasi terhadap Produktivitas}


Berdasarkan hasil pengujian hipotesis diperoleh tingkat signifikansi sebesar 0,021 lebih kecil dari 0,05. Dengan demikian H0 ditolak dan $\mathrm{Ha}$ diterima, artinya bahwa variabel motivasi berpengaruh positif signifikan terhadap produktivitas.

Berdasarkan data tersebut menunjukkan bahwa karyawan mempunyai motivasi yang sangat bagus terhadap pekerjaannya, karena adanya dorongan untuk melakukan kegiatan supaya tercapai tujuanya. Salah satunya adanya gaji dan tunjangan yang menarik bagi karyawan. Orang yang memiliki motivasi tinggi akan tergerak untuk selalu memberikan yang terbaik bagi perusahaan.

Hasil penelitian dari Sutrisno, Azis, F. Maria, M.M. (2016), Sukimim, Patricia D,P., Leonardo, B,H. (2016), Hartanto Susi, H,.Yusni M,. (2018). Di temukan bahwa ada pengaruh yang positip antara motivasi dengan produktivitas karyawan. Motivasi berpengaruh positif ini bermakna bahwa semakin tinggi motivasi maka produktivitas karyawan akan semakin tinggi juga. Begitu pula sebaliknya semakin rendah motivasi maka produktivitas karyawan tersebut akan semakin rendah.

\section{Pengaruh pengalaman terhadap Produktivitas}

Berdasarkan hasil pengujian hipotesis dengan uji t menunjukkan tingkat signifikansi sebesar 0,026 yang kurang dari 0,05. Dengan demikian $\mathrm{HO}$ ditolak dan Ha diterima, artinya bahwa variabel pengalaman berpengaruh positif signifikan terhadap produktivitas.

Hal ini menunjukkan bahwa karyawan yang mempunyai pengalaman kerja yang lama di bidang kredit mikro akan lebih mudah beradaptasi dengan lingkungan kerja, karena dengan pengalaman tersebut karyawan dapat mendapatkan hasil yang lebih cepat, selain itu juga dapat menyelesaikan tugas-tugas secara efektif dan efisien.

Hasil penelitian dari Ahmad Nur Rofi (2012), Ardika Sulaeman (2014), Haedar dan Suandi Putra Syamsuddin (2014). Di temukan bahwa ada pengaruh yang positif antara pengalaman kerja dengan produktivitas karyawan. Pengalaman kerja berpengaruh positif ini bermakna bahwa semakin tinggi pengalaman kerja maka produktivitas karyawan akan semakin tinggi juga. Begitu juga sebaliknya semakin rendah pengalaman kerja maka produktivitas karyawan tersebut akan semakin rendah.

\section{KESIMPULAN}

Berdasarkan penelitian tentang analisis pengaruh disiplin, motivasi dan pengalaman terhadap produktivitas, maka dapat disimpulkan bahwa:

1. Disiplin, sebagai variabel $\mathrm{X} 1$ tidak ada pengaruh positif terhadap produktivitas sebagai variabel Y. Dengan nilai koefisiensi sebesar 3,241 dan nilai signifikansi sebesar 0,904 yang lebih dari $0,05 \quad(\alpha=5 \%)$. Sehingga dapat disimpulkan bahwa karyawan area layanan mikro cabang pemalang masih rendah.

2. Motivasi, sebagai variabel X2 ada pengaruh positif terhadap produktivitas sebagai variabel Y. Ditunjukkan dengan nilai koefisien regresi sebesar 1,476 dan nilai signifikansi sebesar 0,021 yang kurang dari 0,05 . Sehingga dapat disimpulkan bahwa semakin besar motivasi seorang karyawan maka semakin tinggi pula produktivitas.

3. Pengalaman, sebagai variabel X3 ada ppengaruh positif terhadap produktivitas sebagai variabel $Y$. Ditunjukkan dengan nilai koefisien regresi sebesar 0,988 dan nilai signifikansi sebesar 0,026 yang kurang dari 0,05. Sehingga dapat disimpulkan bahwa semakin banyak pengalaman yang dimiliki seorang karyawan maka semakin tinggi pula produktivitas.

4. Dalam penggunaan model uji regresi linier berganda nilai koefisien determinasi menunjukkan nilai Adjusted R2 sebesar 0,289 dimana hal ini memiliki arti bahwa variabel bebas (X) yang terdiri dari disiplin (X1), motivasi (X3), dan pengalaman (X3) memiliki kontribusi terhadap variabel terikat (Y) yaitu produktivitas sebanyak $28,9 \%$ sedangkan sisanya $71,1 \%$ dipengaruhi oleh faktor-faktor lain diluar variabel yang diteliti pada penelitian ini. Faktor tersebut seperti sikap kerja, tingkat ketrampilan, hubungan antara tenaga kerja dan pimpinan organisasi, manajemen 
produktifitas, efisiensi tenaga kerja, dan kewiraswastaan.

\section{DAFTAR PUSTAKA}

Arep Ishak \& Tanjung Hendri, 2003, manajemen Motivasi. Jakrta: PT. Gramedia Widiasarana Indonesia.

Arikunto, Suharsimi. 2006. Prosedure Penelitian Suatu Pendekatan Praktek. Jakarta: PT. Rineka Cipta. Bhuana Ilmu Populer.

Bae, J. \& Lawler, J.J. 2001, Organizational and HRM strategies in Korea: impact on firm performance in an emerging economy. Academy of Management Journal, 43(3), 502-517.

Bafadal. 2003. Peningkatan Profesional Guru dalam kerangka Menajemen Peningkatan Mutu Berbasis Sekolah. Jakarta: Bumi Aksara.

Bernardin, H. John, dan Joyce E.A Russel. 2003. Human resource management (An Experimental Approach International Edition). Mc. Graw-Hill Inc. Singapore.

Bill Foster dan Karen R. Seeker, 2001. "Pembinaan Untuk Meningkatkan Kinerja Karyawan"Jakarta: PT.Toko Gunung Agung Tbk.

Byars, Llloyd L dan Rue, Leslie W. 2006. Human Resource Management, 8 edition. MCGraw-Hill, Irwin

Depdiknas. 2001. Kamus Besar Bahasa Indonesia, Jakarta : Balai Pustaka. Ghozali, H. Imam. 2006. Aplikasi Analisis Multivariat Dengan Program SPSS. Semarang: Badan Penerbit Univerbit UNDIP.

Gomes, F. Cardoso. 2006. Manajeman sumber daya manusia. Yogyakarta: Andi Offset

Guest, D. 2007. Black pod: Diverse pathogens with a global impact on cocoa yield. Phytopathology 97 (12) Hal.16501653.

Hasibuan Malayu S.P. 2005. Organisasi Dan Motivasi; Dasar Peningkatan Produktivitas. Jakarta: Bumi Aksara.

---------2009. Manajemen Sumber Daya Manusia. Jakarta: PT. Bumi Aksara. -2010. Manajemen Sumber Daya Manusa. Jakarta: Bumi Aksara.

Hadari, Nawawi. 2005. Metode Penelitian Bidang Sosial. Yogyakarta: Gadjah Mada University Press.
Hartono, Jogiyanto. 2008. "Teori Portofolio Dan Analisis Investasi”.BPFE , Yogyakarta

Indriantoro, Nur dan Supomo, 2002, "Metodologi Penelitian Bisnis Untuk Akuntansi dan Manajemen, Edisi Pertama, Yogyakarta : BPFE. 95

Mathis, Robert L. dan John H. Jackson. 2006. Manajemen Sumber Daya Manusia, Edisi Pertama Salemba Empat, Jakarta.

Moekizat. 2010. Manajemen Sumber Daya Manusia: Manajemen Kepegawaian. Jakarta: Mandar Maju.

Mulyadi dan Johny Setyawan. 2001. Sistem Perencanaan \& Pengendalian Manajemen. Edisi ke-2. Cetakan ke-1. Jakarta: Salemba Empat, hlm 474

Nana Sudjana 2006. Penilaian Hasil Proses Belajar Mengajar. Bandung: PT Remaja Rosdakarya.

Notoadmodjo, 2009. Pengembangan Sumber Daya Manusia. Jakarta: Rineka Cipta

Peraturan Pemerintah Nomor 14 Tahun 1994 tentang Diklat Jabatan Pegawai Negeri Sipil.

Peraturan Menteri Pendidikan Nasional Republik Indonesia Nomor 13 Tahun $2007 . \quad$ TentangStandarKepala Sekolah/Madrasah, Jakarta: BSNP 2007

Peraturan Pemerintah Republik Indonesia Nomor 74 tahun 2008.Tentang Guru, Jakarta.

Rivai, Veithzal. 2009. Manajemen Sumber Daya Manusia Untuk Perusahaan Dari Teori ke Praktik. Jakarta: Raja Grafindo Persada.

Robbin, P.Stephen. 2003. Perilaku Organisasi, Jilid I. Terjemahan Handyana Pudja Atmaka. Jakarta: Prenhallindo.

Robbins. Stephen P. dan Judge Timothy A. 2008. Perilaku Organisasi edisi 12 terjemahan (Organizational Behavior). Jakarta:Salemba Empat.

Singgih Santoso. 2002. SPSS Versi 11.5 Cetakan Kedua Jakarta: Gramedia.

Simanjuntak, Payaman. 2001. Pengantar Ekonomi Sumber Daya Manusia. Jakarta: LPFEUI

Simanjuntak, Payaman J. 2005. Manajemen dan Evaluasi Kinerja. Jakarta: FE UI.

Simamora, H. 2004. Manajemen Sumber Daya Manusia. Yogyakarta: Sekolah Tinggi Ilmu Ekonomi YKPN 
Soedjono. 2005. Pengaruh Budaya Organisasi terhadap Kinerja Organisasi dan kepuasan Kerja Karyawan pada Terminal Penumpang Umum di Surabaya. Jurnal Manajemen dan kwirausahaan Vol. 7 No. 1. STIESIA Surabaya.

Sunyoto, Danang. 2013. Teori, kuisener, dan Proses Analisis data perilaku Organisasional. Yogyakarta : CAPS (Center Acadeic Publishing Service). 96

Sunarto, Noor, Sahedhy. 2001. Manajemen Sumber Daya Manusia. Yogyakarta: Pena Persada Offset.

Sugiyono. 2007. Statistika untuk Penelitian. Bandung: Alfabeta

Sugiyono. 2010. Metode Penelitian Pendidikan Pendekatan Kuantitatif, Kualitatif dan R \& D, Bandung: Alfabeta

Sutrisno, Edi. 2009. Manajemen Sumber Daya Manusia Edisi pertama. Jakarta: Kencana Prenada Media Group 